\title{
Nomograms as Predictive Tools for Prostate Cancer Patients Who Had Radical Prostatectomy
}

\author{
Saadettin Eskicorapci ${ }^{1}$, Cenk Acar ${ }^{1}$, Zafer Sinik ${ }^{1}$, Zafer Aybek ${ }^{1}$, Michael Kattanb ${ }^{2}$ \\ ${ }^{1}$ Department of Urology, Pamukkale University School of Medicine, Denizli, Turkey \\ ${ }^{2}$ Department of Quantitative Health Sciences, Cleveland Clinic, Cleveland, USA \\ E-mail: drsye@yahoo.com \\ Received March 22, 2011; revised May 9, 2011; accepted May 18, 2011
}

\begin{abstract}
Prostate cancer is the most common solid cancer for men in the developed countries. Radical prostatectomy is the most preferred treatment modality for localized prostate cancer. Individual decision making is necessary for each patient because of the diversities in the biological characteristics of the prostate cancer. The prediction of pathologic stage, prognosis and cancer specific mortality after curative therapy and quality of life issues are essential for counseling and tailoring treatment in possible candidates of radical prostatectomy. Several studies demonstrated that nomograms are the best predictive tools regarding the other prediction models. For better understanding the nomograms in radical prostatectomy patients, they should be classified according to categories for their use. PSA, Gleason grade and clinical stage are seemed to be the most important prognostic factors in patients who are candidates for radical prostatectomy. Additionally, the pathological parameters are remarkable prognostic criteria. The Partin tables for predicting the radical prostatectomy pathology and Kattan nomograms for predicting the biochemical recurrences free survival rates are the most frequently used nomograms. Today, these nomograms should not replace the clinical decisions but they give significant information for the patients' prognosis, treatment selection and follow up.
\end{abstract}

Keywords: Nomogram, Prediction, Prostate Cancer, Prognosis, Radical Prostatectomy

\section{Introduction}

Prostate cancer is the most common solid cancer for men in the developed countries [1]. Radical prostatectomy is the most preferred treatment modality for localized prostate cancer. Individual decision making is necessary for each patient because of the diversities of the biological characteristics of the prostate cancer. [2]. Selection of proper treatment for individual patient is crucial to improving the propensity of cure and survival. The prediction of pathologic stage, prognosis and cancer specific mortality after curative therapy and quality of life issues are essential for counseling and tailoring treatment in possible candidates of radical prostatectomy. Researchers have developed predictive and prognostic tools that are based on statistical models for making more accurate risk estimation. Contemporarily, these tools are nomograms, risk groupings, artificial neural networks (ANN), probability tables such as "Partin staging tables" and CART (classification and regression tree) analyses [3-8]. Several studies demonstrated that nomograms are the best predictive tools regarding the other prediction models $[9,10]$.

\section{What Is a Nomogram?}

Statistically, a nomogram is defined as graphical calculating scale for related mathematical formula. In medical science, nomograms are the methods for predicting specific outcome (biochemical recurrences for prostate cancer, breast cancer mortality etc.) and prognosis by using the significantly prognostic parameters of the disease. For prostate cancer, it is aimed to make an assumption by using the prostate cancer data (prostate specific antigen (PSA), digital rectal examination (DRE), Gleason score, age, race, etc.) (3). Despite the fact that nomograms are developed for each stage of the prostate cancer, they have intensively been studied for localized prostate cancer in recent years. Commonly used nomograms are Partin nomogram (tables) for predicting the radical prostatectomy (RP) pathology and Kattan nomograms for predicting biochemical recurrences free survival [2]. 
The prediction accuracy of nomograms should absolutely be assessed and validated internally and externally. However, the application of such nomograms may be nonsense without understanding relationship between the parameters. To better understanding the nomograms in prostate cancer, they should be classified according to categories for their use (Table 1).

In this review, we discussed the prediction models associated with radical prostatectomy (RP).

\subsection{Nomograms for Prediction of Pathological Parameters after Rp (Table 2)}

Radical prostatectomy is frequently preferred treatment options for organ confined prostate cancer. In order to predict the pathology of the RP and the most suitable treatments for particular patients, several nomograms have been developed [2]. In these nomograms, the Preoperative parameters are used such as PSA, Gleason score, clinical stage, cancer volume in biopsy and PSA density.

\subsubsection{The Predictions for Pathological Stage (Partin Look-up Tables and Others)}

In 1987, Oesterling et al. developed a multiple logistic regression analysis to predict the pathological stage by using prostate acid phosphatase (PAP), clinical stage and Gleason grade for 275 patients and it was the first publication in this topic [11]. Later, Narayan et al. set up the probability graphics by using the clinical stage, PSA, Gleason grade and transrectal ultrasonography [12]. Sub- sequently, the "Partin" look-up tables were developed to predict the pathological stage are the frequently used models.

The Partin tables are first formulated through the patients' data at Johns Hopkins University in 1993 [3]. The Partin Tables were updated in 1997, 2001 and 2007 [13-15]. The aim of the Partin Tables is to predict the pathological stage using 3 pre-operative parameters as clinical stage (TNM classification), Gleason grade and serum PSA. In clinical practice, it is performed in order to determine the probabilities for organ-confined diseases, seminal vesicular and lymph node involvement.

The prediction accuracy of any nomogram should be tested through validation (approval) processes, is conducted by the other data sets or populations. The Partin tables were validated by Blute et al. at Mayo Clinic in 2000 and by Greafen et al. on European patients in 2003 . They stated that use of Partin tables is appropriate for both groups [16,17]. Also, Augustin et al. firstly compared the two Partin tables (1997 and 2001) and validated in 2004 [18]. The validation of 2007 Partin tables was accomplished by using SEER (Surveillance Epidemiology and End Results) database of American National Cancer Institute in early 2010. They found that the discrimination power of Partin tables for seminal vesical and lymph node involvement was high but is limited for predicting extracapsular extension and localized disease [19].

Owing to rising PSA screening over the years in the world, increased number of organ confined cancer was diagnosed due to early detection of prostate cancer in our

Table 1. Classification of nomograms for prediction of radical prostatectomy related outcomes.

1) Nomograms for predicting pathological parameters and stages after RP

- $\quad$ The predictions for pathological stage (Partin tables and others)

- Nomograms to predict the organ confined diseases and extracapsular involvement

- Nomograms for the prediction of SV invasion and lymph node involvement

- Nomograms to predict the surgical margin status

- Nomograms to predict the Gleason score upgrade

- Nomograms to predict the location of the tumor (peripheral zone and transitional zone) and tumor volume

- Nomograms to predict clinically insignificant cancers

2) Nomograms to predict PSA recurrence/disease free/general survival after RP

- Nomograms with the data prior to RP

- $\quad$ Nomograms with the data after RP

3) Nomograms to predict Prostate Cancer Specific Mortality After RP

4) Nomograms to predict the quality of life after RP

RP: Radical Prostatectomy; SV: Seminal Vesicle. 
Table 2. Nomograms for predicting pathological parameters in radical prostatectomy.

\begin{tabular}{|c|c|c|c|c|c|}
\hline Referrence & Predictions & Parameters & $\begin{array}{c}\text { Number of } \\
\text { patients }\end{array}$ & Accuracy $(\%)$ & Validation \\
\hline $\begin{array}{l}\text { Narayan } \\
\text { et al. [12] }\end{array}$ & Pathologic stage & Biopsy based Stage, Biopsy Gleason sum, PSA & 813 & Non-specified & NA \\
\hline $\begin{array}{l}\text { Partin } \\
\text { et al. [3] }\end{array}$ & Pathologic stage & Clinical stage, Biopsy Gleason sum, PSA & 703 & Non-specified & $\begin{array}{l}\text { Externally } \\
\text { and updated }\end{array}$ \\
\hline $\begin{array}{l}\text { Partin } \\
\text { et al. }[14]\end{array}$ & Pathologic stage & Clinical stage, Biopsy Gleason sum, PSA & 4133 & 72 & $\begin{array}{l}\text { Internally and } \\
\text { Externally }\end{array}$ \\
\hline $\begin{array}{l}\text { Badalament } \\
\text { et al. [20] }\end{array}$ & $\begin{array}{l}\text { Organ-confined } \\
\text { disease }\end{array}$ & $\begin{array}{l}\text { Clinical stage, PSA, ratio of positive cores, } \\
\text { percentage of positive cores }\end{array}$ & 192 & 86 & NA \\
\hline $\begin{array}{l}\text { Ohori } \\
\text { et al. [21] }\end{array}$ & $\begin{array}{l}\text { Side specific } \\
\text { extracapsular } \\
\text { extension }\end{array}$ & $\begin{array}{l}\text { PSA, Clinical stage, Biopsy Gleason sum (side } \\
\text { specific), percentage positive cores (side specific), } \\
\text { percentage of cancer in cores (side specific) }\end{array}$ & 763 & 81 & Externally \\
\hline $\begin{array}{l}\text { Steuber } \\
\text { et al. [22] }\end{array}$ & $\begin{array}{l}\text { Side specific } \\
\text { extracapsular } \\
\text { extension }\end{array}$ & $\begin{array}{l}\text { PSA, Clinical stage, Biopsy Gleason sum, percentage } \\
\text { positive cores, percentage of cancer in positive cores }\end{array}$ & 1118 & 84 & Internally \\
\hline $\begin{array}{l}\text { Satake } \\
\text { et al. [23] }\end{array}$ & $\begin{array}{l}\text { Side specific } \\
\text { Extracapsular } \\
\text { extension }\end{array}$ & $\begin{array}{l}\text { PSA, Clinical stage, biopsy Gleason sum,maximum } \\
\text { precent of cancer on each side }\end{array}$ & 354 & 79.9 & Internally \\
\hline $\begin{array}{l}\text { Koh } \\
\text { et al. }[24]\end{array}$ & $\begin{array}{l}\text { Seminal vesical } \\
\text { invasion }\end{array}$ & $\begin{array}{l}\text { PSA, Clinical stage, primary ve secondary Gleason } \\
\text { sum, percentage of cancer at base }\end{array}$ & 763 & 88 & Internally \\
\hline $\begin{array}{l}\text { Baccala } \\
\text { et al. }[25]\end{array}$ & $\begin{array}{l}\text { Seminal vesical } \\
\text { invasion }\end{array}$ & Age, PSA, Biopsy Gleason sum, Clinical stage & 6740 & 80 & Internally \\
\hline $\begin{array}{l}\text { Gallina } \\
\text { et al. }[26]\end{array}$ & $\begin{array}{l}\text { Seminal vesical } \\
\text { invasion }\end{array}$ & $\begin{array}{l}\text { PSA, Clinical stage, Biopsy Gleason sum, percentage } \\
\text { positive cores }\end{array}$ & 896 & 79 & $\begin{array}{l}\text { Internally ve } \\
\text { Externally }\end{array}$ \\
\hline $\begin{array}{l}\text { Ohori } \\
\text { et al. [27] }\end{array}$ & $\begin{array}{l}\text { Seminal vesical } \\
\text { invasion }\end{array}$ & $\begin{array}{l}\text { PSA, Clinical Stage, Biopsy Gleason score, presence } \\
\text { of cancer at base }\end{array}$ & 466 & 87 & Internally \\
\hline \multirow{2}{*}{$\begin{array}{l}\text { Cagiannos } \\
\text { et al. [28] }\end{array}$} & \multirow{2}{*}{$\begin{array}{l}\text { Lymph node } \\
\text { involvement } \\
\quad \text { (limited) }\end{array}$} & 1) PSA, Clinical stage, Biopsy Gleason sum & & 76 & Internally \\
\hline & & $\begin{array}{l}\text { 2) PSA, Clinical stage, Biopsy Gleason sum, } \\
\text { institution }\end{array}$ & 5510 & 78 & Internally \\
\hline \multirow{3}{*}{$\begin{array}{l}\text { Briganti } \\
\text { et al. [29] }\end{array}$} & \multirow{3}{*}{$\begin{array}{l}\text { Lymph node } \\
\text { involvement } \\
\text { (extended) }\end{array}$} & 1) PSA, Clinical stage, Biopsy Gleason sum & 602 & 76 & Internally \\
\hline & & $\begin{array}{l}\text { 2) PSA, Clinical stage, Biopsy Gleason sum, number } \\
\text { of lymph node }\end{array}$ & 781 & 79 & Internally \\
\hline & & $\begin{array}{l}\text { 3) PSA, Clinical stage, Biopsy Gleason score, } \\
\text { percentage positive cores }\end{array}$ & 278 & 83 & Internally \\
\hline Choi et al. [30] & $\begin{array}{l}\text { Pelvic lymph node } \\
\text { involvement }\end{array}$ & $\begin{array}{l}\text { Age, PSA, biopsy Gleason sum, positive cores ratio, } \\
\text { maximum percent of tumor in any core }\end{array}$ & 945 & 79.9 & Internally \\
\hline $\begin{array}{l}\text { Chun et al. } \\
\qquad \text { [31] }\end{array}$ & Gleason upgrade & $\begin{array}{l}\text { PSA, Clinical stage, primary ve secondary Gleason } \\
\text { sum }\end{array}$ & 2982 & 80 & Internally \\
\hline $\begin{array}{l}\text { Chun et al. } \\
\qquad \text { [32] }\end{array}$ & $\begin{array}{c}\text { Clinically } \\
\text { significant } \\
\text { Gleason upgrade }\end{array}$ & PSA, Clinical stage, Biopsy Gleason sum & 4789 & 76 & Internally \\
\hline $\begin{array}{l}\text { Stackhouse } \\
\text { et al. [33] }\end{array}$ & Gleason upgrade & $\begin{array}{l}\text { Age, biopsy Gleason sum, PSA, prostate weight, } \\
\text { positive-to-total core ratio, maximum percent of } \\
\text { cancer in cores }\end{array}$ & 1701 & 72.4 & Internally \\
\hline $\begin{array}{l}\text { Steuber } \\
\text { et al. [34] }\end{array}$ & $\begin{array}{l}\text { Tumor Location } \\
\text { (TZ vs PZ) }\end{array}$ & $\begin{array}{l}\text { PSA, Biopsy Gleason sum, positive core ratio at } \\
\text { midprostate only, number of positive cores at base, } \\
\text { cumulative percentage biopsy tumor volume }\end{array}$ & 945 & 77 & Internally \\
\hline
\end{tabular}




\begin{tabular}{|c|c|c|c|c|c|}
\hline $\begin{array}{l}\text { Peller } \\
\text { et al. [35] }\end{array}$ & Tumor volume & $\begin{array}{l}\text { Biopsy Gleason sum, number positive sextant cores } \\
\text { and PSA }\end{array}$ & 102 & Non-specified & NA \\
\hline \multirow{3}{*}{$\begin{array}{l}\text { Kattan } \\
\text { et al. [36] }\end{array}$} & \multirow{3}{*}{$\begin{array}{c}\text { Clinically indolent } \\
\text { cancer (tumor } \\
\text { volume }<0.5 \mathrm{~cm}^{3}, \\
\text { organ confined } \\
\text { and gleason grad } \\
\mathrm{e}<4 \text { ) }\end{array}$} & 1) PSA, primary ve secondary Gleason sum & \multirow{3}{*}{409} & 64 & Internally \\
\hline & & $\begin{array}{l}\text { 2) PSA, TRUS volume, primary ve secondary } \\
\text { Gleason sum, percentage positive core }\end{array}$ & & 74 & Internally \\
\hline & & $\begin{array}{l}\text { 3) PSA, Clinical stage, TRUS volume, primary ve } \\
\text { secondary Gleason sum, milimeter of the positive } \\
\text { core, milimeter of the negative core }\end{array}$ & & 79 & Internally \\
\hline
\end{tabular}

country as same. Validation of the Partin nomograms has been conducted by Eskiçorapçı et al. with the participation of 1043 patients from 13 different centers in Turkish population [37]. In conclusion, the urologists should be keeping in mind that the Partin tables are only beneficial for predicting the pathological stage but not prognosis or biochemical recurrences.

\subsubsection{Nomograms to Predict the Organ Confined Diseases and Extracapsular Involvement}

Badalament et al. have developed a formula which calculates the probability for organ confined disease by using Gleason grade, nuclear grade, PSA and tumor involvement rates [20]. Later, the models which was calculating the probability of extracapsular involvement by using the Gleason grade, age, PSA and tumor involvement rates have been established and some of them were validated [38]. These models are not widely used because of complexity of the parameters (nuclear grade, total tumor involvement rate etc.). Partin tables may predict the extracapsular involvement but it fails to locate the effected side. Therefore, Ohori et al. and Steuber et al. developed the specific prediction nomograms for side specific extracapsular involvement [21,22].

\subsubsection{Nomograms for the Prediction of SV Invasion and Lymph Node Involvement}

The prediction of seminal vesicle and lymph node involvement is very important because these patients have generally worse prognosis and the success rate of radical surgery or radiotherapy is very low. Predictions for these patients have advantages in order to select the proper adjuvant treatment. Many researchers have been developed the models to predict the seminal vesicle and lymph node involvement [24-26]. However, these models could not take place in clinical practice due to diagnosing the diseases at earlier stages and founding more comprehensive prediction models like Partin tables. On the other hand, Ohori et al. recently developed a nomogram which predicts seminal involvement by using PSA, clinical stage, Gleason sum and cancer at the base. It was stated the accuracy of the nomogram was $87 \%$ [27]. The results of this nomogram are promising.

Eventually, Cagiannos et al. developed a prediction model for limited lymph node dissection and Briganti et al. developed for extended lymph node dissection. These nomograms may be helpful to make a decision for selecting the patients who need lymphadenectomy $[28,29]$.

\subsubsection{Nomograms to Predict the Surgical Margin Status}

The positivity of surgical margin is an important prognostic parameter for the prediction of PSA relapse after RP. However, none of the nomograms predicting the surgical margin has been validated to date and they are not widely used $[39,40]$.

\subsubsection{Nomograms to Predict the Gleason Score Upgrade in RP}

Gleason grade of RP is generally higher than the biopsy Gleason grade. D'Amico et al. developed a nomogram to predict the Gleason score upgrade and has recently been validated [7,31]. In addition, Chun et al. have developed a model to predict the high increases in Gleason grade with their nomograms and was internally validated [32]. Stackhouse et al. conducted a nomogram by using age, PSA, prostate volume, biopsy Gleason sum, ratio of positive biopsy core and maximum percentage of cancer in cores. The accuracy of nomogram was $72.4 \%$ [33]. Capitonio et al. developed their nomograms by using PSA, clinical stage, primary and secondary Gleason score in biopsy. The concordance index (c-index) was calculated as $74.89 \%$ [41]. These nomograms may be used especially for cryotheraphy, HIFU (high intensity focused ultrasonography) and active surveillance.

\subsubsection{Nomograms to Predict the Location of the Tumor (Peripheral Zone and Transitional Zone) and Tumor Volume}

The fact that organ confined disease rate of the transitional zone prostate cancer is higher despite the high PSA levels. Steuber et al. have developed a nomogram for predicting the transitional zone prostate cancer which c-index was 77\% [34]. Peller et al. have developed another nomogram to predict the tumor volume in the prostate. However, this nomogram could not be widely used in view of including small number of patients and data of sextant biopsy [35]. 


\subsubsection{Nomograms to Predict Clinically Insignificant Cancers}

The most of prostate cancers are clinically insignificant. Besides the nomograms predicting the clinically insignificant prostate cancers, the three nomograms were developed by Kattan et al. is widely used. The nomograms are based on the criteria of Epstein et al. [36]. These nomograms may be useful for the elderly patients with high co-morbidity which require especially conservative approach.

\subsection{Nomograms to Predict Biochemical Recurrence, Disease Free and General Survival after RP (Table 3)}

\subsubsection{Nomograms with the Data Prior to RP}

After the Partin tables which were widely accepted for predicting the pathological stage, nomograms have been developed for prediction of survival which is the primary end point for prostate cancer. The most frequently used nomogram is the pre-operative Kattan nomogram, was firstly developed in 1998 [4]. The Kattan nomogram represents 5 years biochemical recurrence free survival rates by constituting PSA, clinical stage, Gleason grade. Kattan nomogram seems to have some advantages such as easy to apply, predicts progression free survival and defines the requirement of adjuvant treatments. The accuracy of the nomogram is increased by adding İn- terlökin-6 soluble receptor and transforming growth factor beta-1 [42]. In 2006, a new version of Kattan nomogram which predicts 10-years survival was published [43]. In our country, the validation of Kattan nomogram is recently accomplished by Eskicorapci et al. In this study the two pre-operative Kattan nomograms (developed in 1998 and 2006) validated and c-index was found as $68 \%$ and $70 \%$, respectively [44].

The prediction model was developed by D'Amico et al. is similar to the Kattan nomogram [45]. This model predicts 10-years biochemical recurrences free survival with pre-operative PSA, Gleason grade and tumor stage. The patients are divided into three groups:

1) Low risk: Stage T1c - T2a, PSA $\leq 10 \mathrm{ng} / \mathrm{mL}$ and Gleason grade $\leq 6$ (10 years progression free survival is $83 \%)$

2) Medium risk: Phase T2b, PSA $>10 \mathrm{ng} / \mathrm{mL}$ ve $<$ $20 \mathrm{ng} / \mathrm{mL}$ veya Gleason grade $=7$ (10 years progression free survival is $46 \%$ )

3) High risk: Phase T2c, PSA $\geq 20 \mathrm{ng} / \mathrm{mL}$ veya Gleason grade $\geq 8)$ (10 years progression free survival is $29 \%$ )

Both nomograms (D'Amico and Kattan) predict the PSA progression but not mortality. The life survival of most patients is high despite PSA recurrence. These nomograms are useful to identify requirement of adjuvant treatment, predict disease free survival and select the patients for clinical trial.

\subsubsection{Nomograms with the Data after RP}

In 1999, Kattan et al. developed a nomogram to predict 5 years survival by comprising PSA, Gleason grade, capsular invasion, surgical margin status, seminal vesicle invasion and lymph node involvement. (56) These nomograms have been validated and widely used [46]. Stephenson et al. represents a new nomogram to predict 10 years progression free survival with additional parameters [47]. Moul et al. drew up tables predicting 3-5-7 year's survival without recurrence in 2001 [48]. This table is involved with PSA, race, Gleason score of RP and pathological stage. The other researchers namely Han et al., Bauer et al., Blute et al. and D'Amico et al. conducted similar models [49-52].

Recently, Morieira et al. designed a study to determine whether the Postoperative nomograms are affected by race with comparison of 7 nomograms. They stated all nomograms have similar performance regardless of their racial characteristics [53]. In addition, a study conducted to determine the effects of lowered PSA at diagnosis with rising PSA screening over the years leads to the clinical stage migration. They found it does not reduce Postoperative Kattan nomogram prediction accuracy [54]. Furthermore, the nomograms were developed for predicting early ( 2 years) and aggressive ( $9-12$ months) recurrence after radical prostatectomy. Walz et al. set up a nomogram to predict early recurrence with 6 parameters and c-index was found as $82 \%$ [55]. Schroeck et al. developed a nomogram with 8 variables for predicting aggressive biochemical recurrence and compared with nine nomograms. They stated their nomogram is superior for determining aggressive recurrence [56]. Afterwards, they recalibrated and externally validated their nomogram [57].

\subsubsection{Nomograms to Predict Prostate Cancer Specific Mortality after RP}

Prostate cancer related mortality after RP is another important issue for prediction models. Stephenson et al. set up a nomogram to predict 15 years survival and c-index was found as $82 \%$ [58]. Indeed, Porter et al. developed a nomogram with constituting age, pathological stage, pathological Gleason sum, performing lymph node dissection and adjuvant radiotherapy data to determine 20 -year disease-free survival after RP and c-index was $76.3 \%$ [59].

\subsubsection{Nomograms to Predict the Quality of Life after RP}

Although cancer specific survival has always been the 
Table 3. Nomograms to predict biochemical recurrence, disease free and general survival after RP.

\begin{tabular}{|c|c|c|c|c|c|c|}
\hline Referrences & $\begin{array}{c}\text { Pre vs } \\
\text { Postoperative }\end{array}$ & Variables & $\begin{array}{l}\text { Number } \\
\text { of Patients }\end{array}$ & $\begin{array}{l}\text { Biochemical } \\
\text { recurrneces } \\
\text { (year) }\end{array}$ & Accuracy $(\%)$ & Validation \\
\hline $\begin{array}{l}\text { D'Amico } \\
\text { et al. }[51]\end{array}$ & Preoperative & $\begin{array}{l}\text { PSA, Clinical stage, biopsy Gleason } \\
\text { sum, percentage positive cores }\end{array}$ & 823 & 4 & 80 & $\begin{array}{l}\text { Internally and } \\
\text { Externally }\end{array}$ \\
\hline $\begin{array}{l}\text { Kattan et al. } \\
\text { [4] }\end{array}$ & Preoperative & $\begin{array}{l}\text { PSA, Clinical stage, primary ve } \\
\text { secondary biopsy Gleason grade }\end{array}$ & 983 & 5 & 74 & $\begin{array}{l}\text { Internally and } \\
\text { Externally }\end{array}$ \\
\hline $\begin{array}{l}\text { Stephenson } \\
\text { et al. [43] }\end{array}$ & Preoperative & $\begin{array}{l}\text { PSA, Clinical stage, biopsy Gleason } \\
\text { sum, year of surgery, number of } \\
\text { positive ve negative cores }\end{array}$ & $\begin{array}{l}1978 \text { and } \\
1545\end{array}$ & 10 & 76 and 79 & $\begin{array}{l}\text { Internally and } \\
\text { Externally }\end{array}$ \\
\hline $\begin{array}{l}\text { Cooperberg } \\
\text { et al. }[60]\end{array}$ & Preoperative & $\begin{array}{l}\text { Age, DRE, number of previous negative } \\
\text { biopsy, history of HGPIN ve ASAP, } \\
\text { PSA, PSA velocity, family history, time } \\
\text { to first biopsy, time to previous biopsy }\end{array}$ & 1439 & 3 and 5 & 66 & $\begin{array}{l}\text { Internally and } \\
\text { Externally }\end{array}$ \\
\hline $\begin{array}{l}\text { Graefen et al. } \\
\qquad 61]\end{array}$ & Postoperative & $\begin{array}{c}\text { Pathologic stage, volume Gleason } \\
\text { grade } 4 / 5,\end{array}$ & 2393 & 3,5 & 76 & NA \\
\hline $\begin{array}{l}\text { McAleer } \\
\text { et al. }[62]\end{array}$ & Postoperative & $\begin{array}{c}\text { Gleason grade, stage, surgical margin, } \\
\text { PSA }\end{array}$ & 2417 & 7 & Non-specified & Internally \\
\hline $\begin{array}{l}\text { Kattan et al. } \\
\quad[5]\end{array}$ & Postoperative & $\begin{array}{c}\text { PSA, Gleason sum, extracapsular } \\
\text { extension, seminal vesical invasion, } \\
\text { lymph node invasion, surgical margin } \\
\text { status }\end{array}$ & 996 & 5 & 88 & $\begin{array}{l}\text { Internally and } \\
\text { Externally }\end{array}$ \\
\hline $\begin{array}{l}\text { Stephenson } \\
\text { et al. [47] }\end{array}$ & Postoperative & $\begin{array}{c}\text { PSA, Gleason sum, extracapsular } \\
\text { extension, seminal vesical invasion, } \\
\text { lymph node invasion, surgical magrin } \\
\text { status }\end{array}$ & $\begin{array}{l}1881 \\
1782 \text { and } \\
1357\end{array}$ & 10 & $78-86$ & $\begin{array}{l}\text { Internally and } \\
\text { Externally }\end{array}$ \\
\hline $\begin{array}{l}\text { Walz et al. } \\
\qquad 55]\end{array}$ & $\begin{array}{l}\text { Postoperative } \\
\text { Early Recurrence } \\
\quad(<2 \text { years })\end{array}$ & $\begin{array}{l}\text { Age, PSA, pathological Gleason sum, } \\
\text { surgical magrin, extracapsular } \\
\text { extension, seminal vesical invasion } \\
\text { and lymph node invasion }\end{array}$ & 2911 & $\begin{array}{l}\text { Non-specifie } \\
\mathrm{d}\end{array}$ & 82 & $\begin{array}{l}\text { Internally and } \\
\text { Externally }\end{array}$ \\
\hline $\begin{array}{l}\text { Schroeck } \\
\text { et al. [57] }\end{array}$ & $\begin{array}{l}\text { Postoperative } \\
\text { Agressive } \\
\text { Recurrence } \\
\text { (<9 months) }\end{array}$ & $\begin{array}{l}\text { PSA, surgical margin status, seminal } \\
\text { vesical invasion, extracapsular extention, } \\
\text { Gleason score, prostate weight, African } \\
\text { American, year of surgery }\end{array}$ & 2599 & 5 & 83 & $\begin{array}{l}\text { Internally, } \\
\text { Externally and } \\
\text { Recalibrated }\end{array}$ \\
\hline
\end{tabular}

first end point, quality of life should also have an important place after curative treatments. The study which includes Cancer of the Prostate Strategic Urologic Research Endeavor (CaPSURE) data was produced to predict continence, erection status with physical and mental outcomes in the first year after RP [64]. This nomogram predicts characteristics of the preoperative tumors (clinical stage, PSA and Gleason grade) as well as the quality of life prior to surgery. Meanwhile, age and income status as well as co-morbidity were observed independent prognostic factors for prediction of the life quality. In addition, the good physical conditions without co-morbidity and healthy moods may induce rapid recovery to the pre-operative condition.

\section{What Are the Limitations of Nomograms?}

Most of the series constituted the nomograms with pre-operative parameters are developed by retrospective RP data. However, the prediction accuracy of nomograms may be affected by altering the population characteristics over the years. In PSA era, newly diagnosed prostate cancer patients have better stage and grade than before. Therefore, the nomograms should be updated and validated periodically. On the other hand, benefits from diagnosis and treatment of prostate cancer are not homogenous when considering the long clinical course and low mortality. Determining the weight of prognostic factors on prostate cancer outcomes should be defined 
individually and in prediction model at the same time. For this purpose, Kattan nomograms and Albertsen tables are widely used $[65,66]$.

To date, any model has perfect prediction performance. Additionally, some risk factors affecting the prognosis are not included in several nomograms. However, the models cannot achieve $100 \%$ accuracy even if all factors add into the nomograms. To increase the accuracy of nomograms, new biomarkers and imaging techniques have been investigated $[42,67]$.

\section{Conclusions}

Predicting the clinical course of cancer is challenging for all patients. The urologists are willing to predict the pathological stages and possible scenarios after curative interventions. Therefore, the prognostic factors and nomograms are the frequently applied sources. PSA, Gleason grade and clinical stage are considered to be the most important prognostic factors. In addition, the pathological parameters are remarkable prognostic criteria. The Partin tables for predicting the radical prostatectomy pathology and Kattan nomograms for predicting the biochemical recurrences free survival rates are the most frequently used nomograms. Today, these nomograms should not replace the clinical decisions but they give significant information for the patients' prognosis, treatment selection and follow up.

\section{References}

[1] P. Boyle and J. Ferlay, "Cancer Incidence and Mortality in Europe, 2004," Annals of Oncology, Vol. 16, No. 3, 2005, pp. 481-488. doi:10.1093/annonc/mdi098

[2] S. F. Shariat, P. I. Karakiewicz, V. Margulis and M. W. Kattan, "Inventory of Prostate Cancer Predictive Tools," Current Opinion in Urology, Vol. 18, 2008, No. 3, pp. 279-296. doi:10.1097/MOU.0b013e3282f9b3e5

[3] A. W. Partin, J. Yoo, H. B. Carter, J. D. Pearson, D. W. Chan, J. I. Epstein and P. C. Walsh, "The Use of Prostate Specific Antigen, Clinical Stage and Gleason Score to Predict Pathological Stage in Men with Localized Prostate Cancer," Journal of Urology, Vol. 150, 1993, pp. $110-114$.

[4] M. W. Kattan, J. A. Eastham, A. M. Stapleton, T. M. Wheeler and P. T. Scardino, "A Preoperative Nomogram for Disease Recurrence Following Radical Prostatectomy for Prostate Cancer," Journal of the National Cancer Institute, Vol. 90, No. 10, 1998, pp. 766-771. doi:10.1093/jnci/90.10.766

[5] M. W. Kattan, T. M. Wheeler and P. T. Scardino, "Postoperative Nomogram for Disease Recurrence after Radical Prostatectomy for Prostate Cancer," Journal of Clinical Oncology, Vol. 17, No. 5, 1999, pp. 1499-1507.

[6] P. B. Snow, D. S. Smith and W. J. Catalona, "Artificial
Neural Networks in the Diagnosis and Prognosis of Prostate Cancer: A Pilot Study," Journal of Urology, Vol. 152, 1994, pp. 1923-1926.

[7] A. V. D'Amico, R. Whittington, S. B. Malkowicz, D. Schultz, M. Schnall, J. E. Tomaszewski and A. Wein, "A Multivariate Analysis of Clinical and Pathological Factors That Predict for Prostate Specific Antigen Failure after Radical Prostatectomy for Prostate Cancer," Journal of Urology, Vol. 154, No. 1, 1995, pp. 131-138.

[8] M. Graefen, A. Haese, U. Pichlmeier, P. G. Hammerer, J. Noldus, K. Butz, A. Erbersdobler, R. P. Henke, U. Michl, S. Fernandez and H. Huland, "A Validated Strategy for Side Specific Prediction of Organ Confined Prostate Cancer: A Tool to Select for Nerve Sparing Radical Prostatectomy," Journal of Urology, Vol. 165, No. 3, 2001, pp. 857-863.

doi:10.1016/S0022-5347(05)66544-5

[9] F. K. Chun, P. I. Karakiewicz, A. Briganti, J. Walz, M. W. Kattan, H. Huland and M. Graefen, "A Critical Appraisal of Logistic Regression-Based Nomograms, Artificial Neural Networks, Classification and Regression-Tree Models, Look-Up Tables and Risk-Group Stratification Models for Prostate Cancer," British Journal of Urology International, Vol. 99, No. 4, 2007, pp. 794-800. doi:10.1111/j.1464-410X.2006.06694.X

[10] M. W. Kattan, "Comparison of Cox Regression with Other Methods for Determining Prediction Models and Nomograms," Journal of Urology, Vol. 170, No. 6, 2003, pp. S6-S9. doi:10.1097/01.ju.0000094764.56269.2d

[11] J. E. Oesterling, C. B. Brendler, J. I. Epstein, A. W. Kimball Jr. and P. C. Walsh, "Correlation of Clinical Stage, Serum Prostatic Acid Phosphatase and Preoperative Gleason Grade with Final Pathological Stage in 275 Patients with Clinically Localized Adenocarcinoma of the Prostate," Journal of Urology, Vol. 138, No. 1, 1987, pp. 92-98.

[12] P. Narayan, V. Gajendran, S. P. Taylor, A. Tewari, J. C. Presti Jr., R. Leidich, R. Lo, K. Palmer, K. Shinohara and J. T. Spaulding, "The Role of Transrectal UltrasoundGuided Biopsy-Based Staging, Preoperative Serum Prostate-Specific Antigen, and Biopsy Gleason Score in Prediction of Final Pathologic Diagnosis in Prostate Cancer," Urology, Vol. 46, No. 2, 1995, pp. 205-212. doi:10.1016/S0090-4295(99)80195-2

[13] D. V. Makarov, B. J. Trock, E. B. Humphreys, L. A. Mangold, P. C. Walsh, J. I. Epstein and A. W. Partin, "Updated Nomogram to Predict Pathologic Stage of Prostate Cancer Given Prostate-Specific Antigen Level, Clinical Stage, and Biopsy Gleason Score (Partin Tables) Based on Cases from 2000 to 2005," Urology, Vol. 69, No. 6, 2007, pp. 1095-1101. doi:10.1016/j.urology.2007.03.042

[14] A. W. Partin, M. W. Kattan, E. N. Subong, P. C. Walsh, K. J. Wojno, J. E. Oesterling, P. T. Scardino and J. D. Pearson, "Combination of Prostate-Specific Antigen, Clinical Stage, and Gleason Score to Predict Pathological Stage of Localized Prostate Cancer. A Multi-institutional Update," Journal of the American Medical Association, Vol. 277, No. 18, 1997, pp. 1445-1451. 
doi:10.1001/jama.277.18.1445

[15] A. W. Partin, L. A. Mangold, D. M. Lamm, P. C. Walsh, J. I. Epstein and J. D. Pearson, "Contemporary Update of Prostate Cancer Staging Nomograms (Partin Tables) for the New Millennium," Urology, Vol. 58, No. 6, 2001, pp. 843-848. doi:10.1016/S0090-4295(01)01441-8

[16] M. L. Blute, E. J. Bergstralh, A. W. Partin, P. C. Walsh, M. W. Kattan, P. T. Scardino, J. E. Montie, J. D. Pearson, J. M. Slezak and H. Zincke, "Validation of Partin Tables for Predicting Pathological Stage of Clinically Localized Prostate Cancer," Journal of Urology, Vol. 164, No. 5, 2000, pp. 1591-1595. do:10.1016/S0022-5347(05)67035-8

[17] M. Graefen, H. Augustin, P. I. Karakiewicz, P. G. Hammerer, A. Haese, J. Palisaar, J. Blonski, S. Fernandez, A. Erbersdobler and H. Huland, "Can Predictive Models for Prostate Cancer Patients Derived in the United States of America be Utilized in European Patients? A Validation Study of the Partin Tables," European Urology, Vol. 43, 2003, pp. 6-10. doi:10.1016/S0302-2838(02)00497-9

[18] H. Augustin, T. Eggert, S. Wenske, P. I. Karakiewicz, J. Palisaar, F. Daghofer, H. Huland and M. Graefen, "Comparison of Accuracy between the Partin Tables of 1997 and 2001 to Predict Final Pathological Stage in Clinically Localized Prostate Cancer," Journal of Urology, Vol. 171, No. 1, 2004, pp. 177-181. doi:10.1097/01.ju.0000099827.77355.a7

[19] J. B. Yu, D. V. Makarov, R. Sharma, R. E. Peschel, A. W. Partin and C. P. Gross, "Validation of the Partin Nomogram for Prostate Cancer in a National Sample," Journal of Urology, Vol. 183, No. 1, 2010, pp. 105-111. doi:10.1016/j.juro.2009.08.143

[20] R. A. Badalament, M. C. Miller, P. A. Peller, D. C. Young, D. K. Bahn, P. Kochie, G. J. O'Dowd and R. W. Veltri, "An Algorithm for Predicting Nonorgan Confined Prostate Cancer Using the Results Obtained from Sextant Core Biopsies with Prostate Specific Antigen Level," Journal of Urology, Vol. 156, No. 4, 1996, pp. 13751380. doi:10.1016/S0022-5347(01)65590-3

[21] M. Ohori, M. W. Kattan, H. Koh, N. Maru, K. M. Slawin, S. Shariat, M. Muramoto, V. E. Reuter, T. M. Wheeler, and P. T. Scardino, "Predicting the Presence and Side of Extracapsular Extension: A Nomogram for Staging Prostate Cancer," Journal of Urology, Vol. 171, No. 5, 2004, pp. 1844-1849.

[22] T. Steuber, M. Graefen, A. Haese, A. Erbersdobler, F. K. Chun, T. Schlom, P. Perrotte, H. Huland and P. I. Karakiewicz, "Validation of a Nomogram for Prediction of Side Specific Extracapsular Extension at Radical Prostatectomy," Journal of Urology, Vol. 175, No. 3, 2006, pp. 939-944. doi:10.1016/S0022-5347(05)00342-3

[23] N. Satake, M. Ohori, C. Yu, M. W. Kattan, Y. Ohno, A. Miyakawa, T. Hatano and M. Tachibana, "Development and Internal Validation of a Nomogram Predicting Extracapsular Extension in Radical Prostatectomy Specimens," International Journal of Urology, Vol. 17, No. 3, 2010, pp. 267-272.

doi:10.1111/j.1442-2042.2010.02452.x
[24] H. Koh, M. W. Kattan, P. T. Scardino, K. Suyama, N. Maru, K. Slawin, T. M. Wheeler and M. Ohori, "A Nomogram to Predict Seminal Vesicle Invasion by the Extent and Location of Cancer in Systematic Biopsy Results," Journal of Urology, Vol. 170, No. 4, 2003, pp. 1203-1208. doi:10.1097/01.ju.0000085074.62960.7b

[25] A. Baccala Jr., A. M. Reuther, F. J. Bianco Jr., P. T. Scardino, M. W. Kattan and E. A. Klein, "Complete Resection of Seminal Vesicles at Radical Prostatectomy Results in Substantial Long-Term Disease-Free Survival: Multi-Institutional Study of 6740 Patients," Urology, Vol. 69, No. 3, 2007, pp. 536-540. doi:10.1016/j.urology.2006.12.013

[26] A. Gallina, F. K. Chun, A. Briganti, S. F. Shariat, F. Montorsi, A. Salonia, A. Erbersdobler, P. Rigatti, L. Valiquette, H. Huland, M. Graefen and P. I. Karakiewicz, "Development and Split-Sample Validation of a Nomogram Predicting the Probability of Seminal Vesicle Invasion at Radical Prostatectomy," European Urology, Vol. 52, No. 1, 2007, pp. 98-105. doi:10.1016/j.eururo.2007.01.060

[27] M. Ohori, M. W. Kattan, C. Yu, K. Matsumoto, T. Satoh, J. Ishii, A. Miyakawa, A. Irie, M. Iwamura and M. Tachibana, "Nomogram to Predict Seminal Vesicle Invasion Using the Status of Cancer at the Base of the Prostate on Systematic Biopsy," International Journal of Urology, Vol. 17, No. 6, 2010, pp. 534-540. doi:10.1111/j.1442-2042.2010.02513.x

[28] I. Cagiannos, P. Karakiewicz, J. A. Eastham, M. Ohori, F. Rabbani, C. Gerigk, V. Reuter, M. Graefen, P. G. Hammerer, A. Erbersdobler, H. Huland, P. Kupelian, E. Klein, D. I. Quinn, S. M. Henshall, J. J. Grygiel, R. L. Sutherland, P. D. Stricker, C. G. Morash, P. T. Scardino and M. W. Kattan, "A Preoperative Nomogram Identifying Decreased Risk of Positive Pelvic Lymph Nodes in Patients with Prostate Cancer," Journal of Urology, Vol. 170, No. 5, 2003, pp. 1798-1803. doi:10.1097/01.ju.0000091805.98960.13

[29] A. Briganti, F. K. Chun, A. Salonia, A. Gallina, E. Farina, L. F. Da Pozzo, P. Rigatti, F. Montorsi and P. I. Karakiewicz, "Validation of a Nomogram Predicting the Probability of Lymph Node Invasion Based on the Extent of Pelvic Lymphadenectomy in Patients with Clinically Localized Prostate Cancer," British Journal of Urology International, Vol. 98, No. 4, 2006, pp. 788-793. doi:10.1111/j.1464-410X.2006.06318.x

[30] Y. D. Choi, H. S. Yu, K. H. Choi, et al., "Development of Preoperative Nomogram for Predicting Pelvic Lymph Node Invasion in Patients Undergoing Radical Prostatectomy," European Urology, Vol. 9, 2010, p. 590.

[31] F. K. Chun, T. Steuber, A. Erbersdobler, E. Currlin, J. Walz, T. Schlomm, A. Haese, H. Heinzer, M. McCormack, H. Huland, M. Graefen and P. I. Karakiewicz, "Development and Internal Validation of a Nomogram Predicting the Probability of Prostate Cancer Gleason Sum Upgrading between Biopsy and Radical Prostatectomy Pathology," European Urology, Vol. 49, No. 5, 2006, pp. 820-826. doi:10.1016/j.eururo.2005.11.007

[32] F. K. Chun, A. Briganti, S. F. Shariat, M. Graefen, F. 
Montorsi, A. Erbersdobler, T. Steuber, A. Salonia, E. Currlin, V. Scattoni, M. G. Friedrich, T. Schlomm, A. Haese, U. Michl, R. Colombo, H. Heinzer, L. Valiquette, P. Rigatti, C. G. Roehrborn, H. Huland and P. I. Karakiewicz, "Significant Upgrading Affects a Third of Men Diagnosed with Prostate Cancer: Predictive Nomogram and Internal Validation," British Journal of Urology International, Vol. 98, No. 2, 2006, pp. 329-334. doi:10.1111/j.1464-410X.2006.06262.x

[33] D. A. Stackhouse, L. Sun, F. R. Schroeck, J. Jayachandran, A. A. Caire, C. O. Acholo, C. N. Robertson, D. M. Albala, T. J. Polascik, C. F. Donatucci, K. E. Maloney and J. W. Moul, "Factors Predicting Prostatic Biopsy Gleason Sum under Grading," Journal of Urology, Vol. 182, 2009, pp. 118-122. doi:10.1016/j.juro.2009.02.127

[34] T. Steuber, F. K. Chun, A. Erbersdobler, A. Briganti, A. Haese, M. Graefen, T. Schlomm, L. Valiquette, H. Huland and P. I. Karakiewicz, "Development and Internal Validation of Preoperative Transition Zone Prostate Cancer Nomogram," Urology, Vol. 68, No. 6, 2006, pp. 1295-1300. doi:10.1016/j.urology.2006.08.1066

[35] P. A. Peller, D. C. Young, D. P. Marmaduke, W. L. Marsh and R. A. Badalament, "Sextant Prostate Biopsies. A Histopathologic Correlation with Radical Prostatectomy Specimens," Cancer, Vol. 75, No. 2, 1995, pp. 530538.

doi:10.1002/1097-0142(19950115)75:2<530::AID-CNC R2820750216>3.0.CO;2-Y

[36] M. W. Kattan, J. A. Eastham, T. M. Wheeler, N. Maru, P. T. Scardino, A. Erbersdobler, M. Graefen, H. Huland, H. Koh, S. F. Shariat, K. M. Slawin and M. Ohori, "Counseling Men with Prostate Cancer: A Nomogram for Predicting the Presence of Small, Moderately Differentiated, Confined Tumors," Journal of Urology, Vol. 170, No. 5, 2003, pp. 1792-1797. doi:10.1097/01.ju.0000091806.70171.41

[37] S. Y. Eskicorapci, E. Karabulut, L. Turkeri, S. Baltaci, C. Cal, G. Toktas, H. Akpinar, G. Ozer, S. Sozen, R. Tokuc, M. Lekili, A. Soylu, S. Albayrak, H. Sahin, R. Alpar and H. Ozen, "Validation of 2001 Partin Tables in Turkey: A Multicenter Study," European Urology, Vol. 47, No. 2, 2005, pp. 185-189. doi:10.1016/j.eururo.2004.08.002

[38] D. G. Bostwick, J. Qian, E. Bergstralh, P. Dundore, J. Dugan, R. P. Myers and J. E. Oesterling, "Prediction of Capsular Perforation and Seminal Vesicle Invasion in Prostate Cancer," Journal of Urology, Vol. 155, No. 4, 1996, pp. 1361-1367. doi:10.1016/S0022-5347(01)66267-0

[39] D. A. Ackerman, J. M. Barry, R. A. Wicklund, N. Olson and B. A. Lowe, "Analysis of Risk Factors Associated with Prostate Cancer Extension to the Surgical Margin and Pelvic Node Metastasis at Radical Prostatectomy," Journal of Urology, Vol. 150, No. 6, 1993, pp. 18451850.

[40] F. Rabbani, A. Bastar and W. R. Fair, "Site Specific Predictors of Positive Margins at Radical Prostatectomy: An Argument for Risk Based Modification of Technique," Journal of Urology, Vol. 160, No. 5, 1998, pp. 1727-
1733. doi:10.1016/S0022-5347(01)62394-2

[41] U. Capitanio, P. I. Karakiewicz, C. Jeldres, A. Briganti, A. Gallina, N. Suardi, A. Cestari, G. Guazzoni, A. Salonia and F. Montorsi, "The Probability of Gleason Score Upgrading between Biopsy and Radical Prostatectomy Can Be Accurately Predicted," International Journal of Urology, Vol. 16, No. 5, 2009, pp. 526-529. doi:10.1111/j.1442-2042.2009.02270.x

[42] M. W. Kattan, S. F. Shariat, B. Andrews, K. Zhu, E. Canto, K. Matsumoto, M. Muramoto, P. T. Scardino, M. Ohori, T. M. Wheeler and K. M. Slawin, "The Addition of Interleukin-6 Soluble Receptor and Transforming Growth Factor Betal Improves a Preoperative Nomogram for Predicting Biochemical Progression in Patients with Clinically Localized Prostate Cancer," Journal of Clinical Oncology, Vol. 21, No. 19, 2003, pp. 3573-3579. doi:10.1200/JCO.2003.12.037

[43] A. J. Stephenson, P. T. Scardino, J. A. Eastham, F. J. Bianco Jr., Z. A. Dotan, P. A. Fearn and M. W. Kattan, "Preoperative Nomogram Predicting the 10-Year Probability of Prostate Cancer Recurrence after Radical Prostatectomy," Journal of the National Cancer Institute, Vol. 98, No. 10, 2006, pp. 715-717.doi:10.1093/jnci/djj190

[44] S. Y. Eskicorapci, L. Turkeri, E. Karabulut, C. Cal, H. Akpinar, S. Baltaci, K. Baykal, M. W. Kattan and H. Ozen, "Validation of Two Preoperative Kattan Nomograms Predicting Recurrence after Radical Prostatectomy for Localized Prostate Cancer in Turkey: A Multicenter Study of the Uro-Oncology Society," Urology, Vol. 74, No. 6, 2009, pp. 1289-1295.

doi:10.1016/j.urology.2009.03.019

[45] A. V. D'Amico, "Combined-Modality Staging for Localized Adenocarcinoma of the Prostate," Oncology (Williston Park), Vol. 15, No. 8, 2001, pp. 1049-1059.

[46] M. Graefen, P. I. Karakiewicz, I. Cagiannos, et al., "Validation Study of the Accuracy of a Postoperative Nomogram for Recurrence after Radical Prostatectomy for Localized Prostate Cancer," Journal of Clinical Oncology, Vol. 20, No. 20, 2002, pp. 951-956. doi:10.1200/JCO.20.4.951

[47] A. J. Stephenson, P. T. Scardino, J. A. Eastham, et al., "Postoperative Nomogram Predicting the 10-Year Probability of Prostate Cancer Recurrence after Radical Prostatectomy," Journal of Clinical Oncology, Vol. 23, No. 28, 2005, pp. 7005-7012. doi:10.1200/JCO.2005.01.867

[48] J. W. Moul, R. R. Connelly, D. P. Lubeck, J. J. Bauer, L. Sun, S. C. Flanders, G. D. Grossfeld and P. R. Carroll, "Predicting Risk of Prostate Specific Antigen Recurrence after Radical Prostatectomy with the Center for Prostate Disease Research and Cancer of the Prostate Strategic Urologic Research Endeavor Databases," Journal of Urology, Vol. 166, No. 4, 2001, pp. 1322-1327. doi; 10.1016/S0022-5347(05)65761-8

[49] J. J. Bauer, R. R. Connelly, I. A. Seterhenn, J. Deausen, S. Srivastava, D. G. McLeod and J. W. Moul, "Biostatistical Modeling Using Traditional Preoperative and Pathological Prognostic Variables in the Selection of Men at High Risk for Disease Recurrence after Radical Prostatectomy 
for Prostate Cancer," Journal of Urology, Vol. 159, No. 3, 1998, pp. 929-933.

doi:10.1016/S0022-5347(01)63773-X

[50] M. L. Blute, E. J. Bergstralh, A. Iocca, B. Scherer and H. Zincke, "Use of Gleason Score, Prostate Specific Antigen, Seminal Vesicle and Margin Status to Predict Biochemical Failure after Radical Prostatectomy," Journal of Urology, Vol. 165, No. 1, 2001, pp. 119-125. doi:10.1097/00005392-200101000-00030

[51] A. V. D’Amico, R. Whittington, S. B. Malkowicz, J. Fondurulia, M. H. Chen, J. E. Tomaszewski and A. Wein, "The Combination of Preoperative Prostate Specific Antigen and Postoperative Pathological Findings to Predict Prostate Specific Antigen Outcome in Clinically Localized Prostate Cancer," Journal of Urology, Vol. 160, No. 6, 1998, pp. 2096-2101.

[52] M. Han, A. W. Partin, M. Zahurak, S. Piantadosi, J. I. Epstein and P. C. Walsh, "Biochemical (Prostate Specific Antigen) Recurrence Probability Following Radical Prostatectomy for Clinically Localized Prostate Cancer," Journal of Urology, Vol. 169, No. 2, 2003, pp. 517-523. doi:10.1016/S0022-5347(05)63946-8

[53] D. M. Moreira, J. C. Presti Jr., W. J. Aronson, M. K. Terris, C. J. Kane, C. L. Amling, L. L. Sun, J. W. Moul and S. J. Freedland, "The Effect of Race on the Discriminatory Accuracy of Models to Predict Biochemical Recurrence after Radical Prostatectomy: Results from the Shared Equal Access Regional Cancer Hospital and Duke Prostate Center Databases," Prostate Cancer and Prostatic Diseases, Vol. 13, No. 1, 2010, pp. 87-93. doi: $10.1038 /$ pcan. 2009.48

[54] R. Thanigasalam, K. K. Rasiah, P. D. Stricker, A. M. Haynes, S. I. Sutherland, R. L. Sutherland, S. M. Henshall and L. G. Horvath, "Stage Migration in Localized Prostate Cancer Has No Effect on the Post-Radical Prostatectomy Kattan Nomogram," British Journal of Urology International, Vol. 105, No. 5, 2010, pp. 642-647. doi:10.1111/j.1464-410X.2009.08842.x

[55] J. Walz, F. K. Chun, E. A. Klein, A. Reuther, F. Saad, M. Graefen, H. Huland and P. I. Karakiewicz, "Nomogram Predicting the Probability of Early Recurrence after Radical Prostatectomy for Prostate Cancer," Journal of Urology, Vol. 181, No. 2, 2009, pp. 601-608. doi:10.1016/j.juro.2008.10.033

[56] F. R. Schroeck, W. J. Aronson, J. C. Presti Jr., M. K. Terris, C. J. Kane, C. L. Amling and S. J. Freedland, "Do Nomograms Predict Aggressive Recurrence after Radical Prostatectomy More Accurately than Biochemical Recurrence Alone?" British Journal of Urology International, Vol. 103, No. 5, 2009, pp. 603-608. doi:10.1111/j.1464-410X.2008.08118.x

[57] F. R. Schroeck, M. W. Kattan, J. W. Moul, W. J. Aronson, J. C. Presti Jr., M. K. Terris, C. J. Kane, C. L. Amling, L. Sun and S. J. Freedland, "Re-calibration and External Validation of an Existing Nomogram to Predict Aggressive Recurrences after Radical Prostatectomy," British Journal of Urology International, Vol. 105, No. 12, 2010, pp. 1654-1659. doi:10.1111/j.1464-410X.2009.09060.x
[58] A. J. Stephenson, M. W. Kattan, J. A. Eastham, F. J. Bianco Jr., O. Yossepowitch, A. J. Vickers, E. A. Klein, D. P. Wood and P. T. Scardino, "Prostate Cancer-Specific Mortality after Radical Prostatectomy for Patients Treated in the Prostate-Specific Antigen Era," Journal of Clinical Oncology, Vol. 27, No. 26, 2009, pp. 4300-4305. doi:10.1200/JCO.2008.18.2501

[59] C. R. Porter, N. Suardi, U. Capitanio, G. C. Hutterer, K. Kodama, R. P. Gibbons, R. Correa Jr., P. Perrotte, F. Montorsi and P. I. Karakiewicz, "A Nomogram Predicting Prostate Cancer-Specific Mortality after Radical Prostatectomy," Urologia Internationalis, Vol. 84, No. 2, 2010, pp. 132-140. doi:10.1159/000277588

[60] M. R. Cooperberg, D. J. Pasta, E. P. Elkin, M. S. Litwin, D. M. Latini, J. Du Chane and P. R. Carroll, "The University of California, San Francisco Cancer of the Prostate Risk Assessment Score: A Straightforward and Reliable Preoperative Predictor of Disease Recurrence after Radical Prostatectomy," Journal of Urology, Vol. 173, No. 6, 2005, pp. 1938-1942. doi:10.1097/01.ju.0000158155.33890.e7

[61] M. Graefen, J. Noldus, U. Pichlmeier, A. Haese, P. Hammerer, S. Fernandez, S. Conrad, R. Henke, E. Huland and H. Huland, "Early Prostate-Specific Antigen Relapse after Radical Retropubic Prostatectomy: Prediction on the Basis of Preoperative and Postoperative Tumor Characteristics," European Urology, Vol. 36, No. 1, 1999, pp. 21-30. doi:10.1159/000019922

[62] S. J. McAleer, D. Schultz, R. Whittington, S. B. Malkowicz, A. Renshaw, A. Wein, J. P. Richie and A. V. D'Amico, "PSA Outcome Following Radical Prostatectomy for Patients with Localized Prostate Cancer Stratified by Prostatectomy Findings and the Preoperative PSA Level," Urologic Oncology, Vol. 23, No. 5, 2005, pp. 311-317. doi:10.1016/j.urolonc.2004.12.013

[63] A. J. Stephenson, D. P. Wood, M. W. Kattan, E. A. Klein, P. T. Scardino, J. A. Eastham and B. S. Carver, "Location, Extent and Number of Positive Surgical Margins Do Not Improve Accuracy of Predicting Prostate Cancer Recurrence after Radical Prostatectomy," Journal of Urology, Vol. 182, No. 4, 2009, pp. 1357-1363. doi:10.1016/j.juro.2009.06.046

[64] J. C. Hu, E. P. Elkin, D. J. Pasta, D. P. Lubeck, M. W. Kattan, P. R. Carroll and M. S. Litwin, "Predicting Quality of Life after Radical Prostatectomy: Results from CaPSURE," Journal of Urology, Vol. 171, No. 2, 2004 pp. 703-708. doi:10.1097/01.ju.0000107964.61300.f6

[65] P. C. Albertsen, J. A. Hanley, D. F. Gleason and M. J. Barry, "Competing Risk Analysis of Men Aged 55 to 74 Years at Diagnosis Managed Conservatively for Clinically Localized Prostate Cancer," Journal of the American Medical Association, Vol. 280, No. 11, 1998, pp. 975-980. doi:10.1001/jama.280.11.975

[66] M. W. Kattan, D. Giri, K. S. Panageas, A. Hummer, M. Cranor, K. J. Van Zee, C. A. Hudis, L. Norton, P. I. Borgen and L. K. Tan, "A Tool for Predicting Breast Carcinoma Mortality in Women Who Do Not Receive Adjuvant Therapy," Cancer, Vol. 101, No. 11, 2004, pp. 25092515. doi; $10.1002 /$ cncr.20635 
[67] L. Wang, H. Hricak, M. W. Kattan, H. N. Chen, K. Kuroiwa, H. F. Eisenberg and P. T. Scardino, "Prediction of Seminal Vesicle Invasion in Prostate Cancer: Incremental
Value of Adding Endorectal MR Imaging to the Kattan Nomogram," Radiology, Vol. 242, No. 1, 2007, pp. 182188.doi:10.1148/radiol.2421051254 